Binghamton University

The Open Repository @ Binghamton (The ORB)

Fall 2013

\title{
Strategies Outside the Formal Classroom: Nonprofit Management Education in Transparency and Accountability
}

\author{
Susan Appe \\ Binghamton University--SUNY, sappe@binghamton.edu \\ Daniel Barragán
}

Follow this and additional works at: https://orb.binghamton.edu/public_admin_fac

Part of the Public Administration Commons

\section{Recommended Citation}

Appe, S., \& Barragán, D. (2013). Strategies Outside the Formal Classroom: Nonprofit Management Education in Transparency and Accountability. Journal of Public Affairs Education, 19(4), 591-614. Retrieved from http://www.jstor.org/stable/23608977

This Article is brought to you for free and open access by the Public Administration at The Open Repository @ Binghamton (The ORB). It has been accepted for inclusion in Public Administration Faculty Scholarship by an authorized administrator of The Open Repository @ Binghamton (The ORB). For more information, please contact ORB@binghamton.edu. 


\title{
Strategies Outside the Formal Classroom: Nonprofit Management Education in Transparency and Accountability
}

\author{
Susan Appe \\ Binghamton University, SUNY \\ Daniel Barragán \\ Centro Ecuatoriano de Derecho Ambiental \\ [CEDA; Ecuadorian Center for Environmental Law]
}

\begin{abstract}
A demand for nonprofit management training and organizational capacity building exists in Latin America. However, few nonprofit management education (NME) programs in Latin America exist, and there is limited content related to ethics, transparency, and accountability. Using the case of Ecuador, we identify three strategies implemented by nonprofit leaders to cope with limited NME. We find that first, organizations engage in a process of collectivity that seeks to explore and give meaning to civil society in Ecuador. Second, this process leads to the production of knowledge about civil society in Ecuador. And third, based on both the process of collectivity and knowledge production, nonprofit leaders in Ecuador take ownership in the training of nonprofit leaders through several pilot courses related to transparency and accountability. The case of Ecuador reminds public affairs educators that organizations themselves can be successful producers of knowledge that can and should create and inform curricular content.
\end{abstract}

Keywords: nonprofit management education, accountability, transparency, Ecuador

A demand for nonprofit management training and organizational capacity building exists in Latin America. This is especially true given the external pressures -by donors and governments, in particular-for nonprofit organizations in the region to implement transparent management practices and accountability mechanisms. It is also a reflection of the organizations themselves being internally 


\section{S. Appe \& D. Barragán}

interested in more closely observing the values of ethics, transparency, and accountability. Nonprofit organizations ${ }^{1}$ in Latin America are recognized for playing key roles in the provision of public goods and services (Brautigam \& Segarra, 2007; Cabrera \& Vallejo, 1997; Heinrich, 2007; World Bank, 2005). Despite the strong presence of nonprofit organizations and the goods and services they provide, formal nonprofit management education (NME) programs in higher education institutions are not prevalent in the region (Mirabella, Gemelli, Malcolm, \& Berger, 2007). This article acknowledges the limited supply of formal NME programs in Latin America but also observes that since the comparative study by Mirabella et al. (2007), several NME programs - inside and outside of higher education institutionshave emerged in the region. We focus on the lack of curricular content in NME programs that includes transparency and accountability issues, specifically in the country of Ecuador.

We examine strategies used by nonprofit leaders in Ecuador to build knowledge and transfer skills about organizational management and the values of ethics, transparency, and accountability in nonprofit organizations. Scholars posit that how NME programs cope with and adapt to the environmental conditions is a rich topic for inquiry (Bies \& Blackwood, 2008). We find that the same holds true for nonprofit leaders who might not have access to formal NME programs as well as for those who have access to NME programs that might have limited curricular content. How nonprofit leaders cope with and adapt to such environmental conditions (e.g., limited NME programs and/or limited curricular content) deserves attention.

Ecuador is a particularly relevant and rich case because of the challenges involving NME. Formal NME programs are not in heavy supply, and there are ongoing regulatory reforms promoted by the government that target the nonprofit sector, especially regarding transparency and accountability (Barragán, 2010, 2011). We focus our attention, therefore, on NME programs in Ecuador that address transparency and accountability and identify three strategies implemented by nonprofit leaders to cope with current environmental conditions. We find that first, organizations engage in a process of collectivity that seeks to help explore and give meaning to civil society in Ecuador. Second, this process leads to an objective to produce knowledge about civil society in Ecuador. And third, informed by both the process of collectivity and knowledge production, nonprofit leaders in Ecuador take ownership in the training of nonprofit leaders through several pilot courses related to transparency and accountability.

In this article, we first discuss public affairs education and nonprofit studies literatures that inform the research. Second, we introduce our methodological approach. We then elaborate the case study of Ecuador and explain the three strategies taken by nonprofit organizations-collectivity, knowledge production, and training development. In the section on lessons learned, we present ideas to strengthen NME specific to transparency and accountability in Ecuador and the region. The article concludes with how the Ecuadorian case can inform public affairs education in general. 
Strategies Outside the Formal Classroom

\section{LiTERATURE REVIEW}

Although the public administration literature on nonprofit training in Latin America is limited, several threads of scholarship help to shape our inquiry for the case of Ecuador. We intend to build on public affairs education scholarship in regard to the teaching of values and skills related to ethics, transparency, and accountability (Hejka-Ekins, 1988; Martinez, 1998; Menzel, 1997; Worthley \& Grumet, 1983, Wu \& He, 2009, among others). Called what "can't be taught" (Worthley \& Grumet, 1983), ethics education-particularly in public affairs education-sees major challenges. Most often discussed are the issues related to the quantity of ethics training in public affairs curricula (e.g., if an ethics course is required for degree competition or is offered only as an elective, or if ethics is covered as a subject matter across the curricula rather than in a stand-alone ethics class [Hejka-Ekins, 1988]); variation in methodological approaches taken in ethics instruction (Worthley \& Grumet, 1983); and the objectives of ethics in public affairs education programs (Hejka-Ekins, 1988). Questions remain about how to teach ethics (and if it is even possible) and how to teach related concepts, such as transparency and accountability in public affairs education.

Much of the debate on ethics (as well as transparency and accountability) in public affairs education has focused on the U.S. context; however, the issues are indeed relevant in Latin America as well. Freedom of information (FOI) laws and the right-to-know movements in the region have very much shaped how public affairs education is approached. In Mexico, for example, an integral part of securing a long-lasting and permanent culture of transparency is ensuring that students who enter the field have been exposed academically to the principles of transparency (Benavides, 2006). Professors at schools of public administration in formal higher education institutions indicate that their public affairs programs have been updated to include the topic of transparency (Benavides, 2006).

In addition, public affairs education literature is giving more attention to NME programs and their curricular content (Burlingame, 2009; Mirabella \&Young, 2012; O’Neill, 2005; Wish \& Mirabella, 1998). Although there is a growing body of comparative approaches to NME research (see Donmoyer, Libby, McDonald, \& Deitrick, 2012; Jackson, 2009; Mirabella, 2007; Mirabella et al., 2007; Schmitz, Raggo, \& Bruno-van Vijfeijken, 2013), literature on NME has also tended to focus more on the U.S. context. Several conditions have encouraged the growth of NME programs and their attention in the United States. O'Neill (2005) examines the macro-level conditions and finds that in the United States, the professionalization of several fields and the growth of professional programs in universities help explain the rise of NME programs. The increase in the number of management programs, in particular, has fostered the creation of NME programs. Management education was initially organized only in the public and private sectors (O’Neill, 2005), but professional expectations for nonprofit organizations and their personnel have contributed to recognizing the distinctive training and learning needs of nonprofit 


\section{S. Appe \& D. Barragán}

managers (Bies \& Blackwood, 2008; O’Neill, 2005). This situation has further led to the development of formal academic programs in nonprofit management and their growth.

Aside from the general history and evolution of NME, scholars have also covered the debates about the location and content of such programs. However, gaps in the literature still exist. In regard to content, NME literature does not fully address how thoroughly_ or even how-NME programs are addressing the topics of accountability and ethics in their curricula (see Bies \& Blackwood, 2008). Furthermore, attention to location has revealed that NME programs are indeed housed across several types of degree programs and disciplinary settings (Bies \& Blackwood, 2008). Newer research has looked at the relationship between the location and content (Mirabella \& Young, 2012). Mirabella and Young (2012) find that the location of a social entrepreneurship program - in a business school versus a public affairs school-influences the content of the program. Social entrepreneurship programs in business schools focus more on market skills, whereas public affairs schools are more likely to cover a variety of skills that include "market, political, philanthropic, generic management, and leadership skills" (Mirabella \& Young, 2012, p. 55).

In addition to the public affairs teaching and NME literatures, we find that the recent scholarship on transparency, accountability, and the self-regulation of nonprofit organizations is relevant in the case of Ecuador. The Ecuadorian case engages in the emergent scholarly conversation related to accountability mechanisms and self-regulation by nonprofit organizations across the world (Bies, 2010; Bothwell, 2001; Ebrahim, 2003a; 2003b, Prakash \& Gugerty, 2010). Recent scholarship has described and explained nonprofit self-regulation in the United States (Bothwell, 2001) as well as in Asia (Sidel, 2005), Africa (Gugerty, 2008), and Europe (Bies, 2010). However, little academic research in public affairs has covered these trends in Latin America in English. Rather, several research institutions across Latin America have paved the way for further examination. Research institutions like the Communications and Development Institute [Instituto de Comunicación y Desarrollo, ICD] in Uruguay (http://lasociedadcivil.org/) and the Autonomous Institute of Technology of Mexico [Instituto Tecnológico Autónomo de México, ITAM] (www.filantropia.itam.mx), just as examples, have made important contributions in curriculum development and applied research. In addition, as discussed later in this article, research institutions such as the Ecuadorian Center for Environmental Law [Centro Ecuatoriano de Derecho Ambiental, CEDA] have made significant contributions to the field in the context of Ecuador.

Several factors have contributed to concerns about accountability in the nonprofit sector globally. First, the quantity and the growth of nonprofit organizations are significant (Jordan \& van Tuijl, 2006). With this increase, nongovernmental organizations (NGOs) are more likely to receive attention when mishaps and scandals occur (Ebrahim, 2003b; Gugerty, 2008; Jordan \& van Tuijl, 2006; Prakash $\&$ Gugerty, 2010). Second, there are more funding opportunities for organizations, 
particularly in service provision (Gugerty, 2008; Jordan \& van Tuijl , 2006). And third, nonprofit organizations have a growing voice within international politics and advocacy in several global topics such as environmental issues (Jordan \& van Tuijl , 2006) as well as human rights and women's rights (Kaldor, 2003; Keck \& Sikkink, 1997; Wong, 2012).

Although defining accountability for nonprofit organizations is no easy task, several scholars posit explanations. Ebrahim (2003b) defines accountability as "the means through which individuals and organizations are held externally to account for their actions and the means by which they take internal responsibility for continuously shaping and scrutinizing organizational mission, goals, and performance" (Ebrahim, 2003b, p. 194). Accountability includes not only external accountability (nonprofits are held responsible for their actions) but also internal accountability - nonprofits must hold themselves to higher standards, open themselves up to critiques from the public and the state, and be true to their objectives (Ebrahim, 2003a; see also Jordan \& van Tuijl, 2006; Kaldor, 2003; Najam, 1996). Furthermore, research on nonprofit organizations has addressed what can be called the accountability gap (Schmitz et al., 2013, p. 2) between upward (e.g., donors) and downward (e.g., constituents, beneficiaries) accountability (Bebbington, Hickey, \& Mitlin, 2008; Dagnino, 2008; Schmitz et al., 2013).

Concerns about accountability have driven several types of responses. Governments have become more likely to address regulatory frameworks and remedy shortcomings as they relate to accountability. Some governments have implemented restrictive regulatory laws and others more enabling regulatory laws toward nonprofit organizations in order to ensure civil society accountability (Brysk, 2000; ICNL, 2006, 2009; Rutzen \& Shea, 2006; Salamon \& Toepler, 2000). Although governments are major players in the regulation of nonprofit organizations, increasingly scholars and practitioners note two other types of entities: watchdog/third-party organizations and what Schmitz et al. (2013) call special initiatives. Examples of external watchdog or third-party organizations in the United States include entities such as Charity Navigator, GuideStar, and the Better Business Bureau (Schmitz et al., 2013). These types of entities often rely on government documents such as the Internal Revenue Service 990 form in the U.S. context, and they judge accountability based mostly on financial efficiency: what Schmitz et al. (2013) observe as upward accountability toward donors.

Special initiatives (Schmitz et al., 2013) are also becoming more common across contexts. Examples of these include what Prakash and Gugerty (2010) call voluntary accountability clubs, also called self-regulation regimes (Gugerty, 2008). These entities create standards or guidelines that organizations voluntarily follow. These special initiatives seek to mitigate "agency slippages," which can occur when nonprofit managers use resources and make decisions that stray from the original agreement between most often the funder (principal) and the nonprofit (agency), but such an agreement could also be between the beneficiary and the nonprofit organization (Gugerty \& Prakash, 2010). Special initiatives often emerge within 


\section{S. Appe \& D. Barragán}

the environment of other accountability checks by government regulation and watchdog oversight and seek to signal quality (Prakash \& Gugerty, 2010), but questions remain as to what information is needed to signal such quality.

Public affairs education literature has indeed laid a foundation for teaching ethics and related topics of transparency and accountability; however, minimal discussion in the literature has included public affairs education in Latin America. Likewise, most NME scholarship has been U.S.-based. The body of research has centered on NME's history and growth, formal NME programs' curricular content, and its department or discipline location in higher education institutions. Although this literature greatly informs public affairs teaching and NME programs, it misses insights that can be generated from nonprofit training-specifically on topics of transparency and accountability-outside of the formal classroom which is prevalent in contexts such as Latin America. Given the limited offerings of NME programs in higher education institutions in Ecuador, we see the emergence of a type of special initiative (Schmitz et al., 2011) — a collective of civil society organizations. The special initiative seeks to produce knowledge on the sector and to develop training opportunities for nonprofit organizations in order to meet external as well as internal demands for transparency and accountability of nonprofit organizations in Ecuador.

\section{Methodological Approach}

This article builds on the literature of public affairs education-specifically NME programs - as well as the debates about accountability within nonprofit organizations. The research is conducted through academic-practitioner collaboration and fits well with core aims of this symposium, specifically getting at "creating and adapting contextually relevant teaching." Given the demand and interest in transparency and accountability through participatory research and content analysis, we explore how nonprofit organizations cope with the lack of formal NME programs and curricular content related to transparency and accountability in Latin America, specifically in Ecuador.

Data for the paper are constructed and collected from three sources. First, data are used from archival documents produced by the Collective of Civil Society Organizations [Colectivo de Organizaciones de Sociedad Civil] in Ecuador; these include, for example, meeting notes as well as related published reports and articles. Second, data are collected and analyzed from dozens of interviews that were conducted with Collective participants during the formation phases of the Collective in 2009 and 2010. Third, data are used from two pilot NME courses in Ecuador carried out by the Ecuadorian Center for Environmental Law (hereafter referred to by its Spanish acronym, CEDA), with the support of the Communications and Development Institute [Instituto de Comunicación y Desarrollo, ICD] in 2010 and the Latin American Faculty of Social Sciences [Facultad Latinoamericana de Ciencias Sociales, FLACSO] in 2011.

We find that these varied sources allow us to present a rich description of the case of Ecuador in order to elicit new research directions and recommendations 
applicable to Ecuador and beyond. We focus on an NME experience outside higher education institutions that addresses specifically transparency and accountability. In the lessons learned section, we provide avenues on how to bridge these NME experiences more with university institutions and recommendations for public affairs education in general.

\section{Strategies for NME in Transparency and Accountability in Ecuador}

We know from social movement theory that when organizations feel threatened, they are more likely to form coalitions (McAdam, McCarthy, \& Zald, 1996; McCarthy \& Zald, 1977). As such, nonprofit studies literature has recognized the proliferation of sector-level organizations and umbrella organizations, sometimes formed in response to government pressures, often with the objectives to improve organizational effectiveness and to represent member organizations in the policy process (Abramson \& McCarthy, 2012; Young, 2001; see also Gugerty, 2008, 2009; Gugerty \& Prakash, 2010). The case of Ecuador first provides us with the formation of an organization initially called the Collective of Civil Society Organizations and what then, in 2013, was formalized into the Ecuadorian Confederation of Civil Society Organizations [Confederación Ecuatoriana de Organizaciones de la Sociedad Civil]. Additionally, the Collective-and one of its organizational partners, CEDA-began to articulate a demand for and then supported the development of capacity-building opportunities for civil society organizations around transparency and accountability. The following sections discuss these three strategies undertaken by nonprofit leaders in Ecuador: the process of collectivity, knowledge production, and training development.

\section{The Process of Collectivity}

As mentioned, one of the challenges facing nonprofit organizations and NME in Ecuador is the ongoing regulatory reform. In 2008, the Presidential Executive Decree No. 982 (Presidencia de la República del Ecuador, 2008) in Ecuador reformed the regulatory framework for civil society organizations. Its stated objectives are to (a) improve the transparency of civil society organizations and (b) establish regulatory accountability mechanisms through the creation and implementation of a registry of civil society organizations and an accreditation process for organizations that receive public funds. ${ }^{2}$ The Decree defines the registry of civil society organizations as a mechanism to keep records of legally recognized civil society and nonprofit organizations and make this information publicly available (Appe, 2011).

In addition to the release of Decree No. 982, in 2008 the government initiated discussion and drafting of a more comprehensive civil society legal framework, hiring a legal consultant group to elaborate a draft law (Grupo Legal Trade, 2009). As a result and parallel to the government-driven process, nonprofit organizations began to meet and discuss the regulation of civil society and the nonprofit sector. This process included 11 civil society networks of around 800 organizations nationwide and 18 of the larger foundations in Ecuador. In addition, several lawyers affiliated with civil society were included in the process for legal advice. From 


\section{S. Appe \& D. Barragán}

April 2008 until January 2009, approximately ten meetings were held among participating organizations and three meetings with the legal consultant group hired by the government. A draft law was circulated by government, and nonprofit organizations were able to make comment, but soon the process would be tabled by the government. Although the process led by government died, it left Ecuadorian nonprofit organizations motivated to continue talking (Garcés, 2010).

The 2008 discussions about a civil society law and the concerns over the newly implemented Decree No. 982 were seen as windows of opportunity for debate and consolidation among some nonprofit organizations in Ecuador. The time seemed to represent a turning point for organizations, as some interview participants noted:

There was not any process on which civil society organizations united, to improve their activities at the country level or strengthening their stance and improve their capacity.

Thus several nonprofit organizations in Ecuador started to meet to debate civil society's role in Ecuador, regulation of organizations, and how transparency and accountability within the sector might be better operationalized. From these discussions, there was a consolidation process of what might be considered a special initiative as defined by Schmitz and colleagues (2013), the Collective of Civil Society Organizations. First as an informal group, the organizations began to tackle larger and broader issues across civil society, as one interview participant reflected:

This Decree called on us...the [group] was created...to handle themes that are not [only] directly related to regulation. Yes, it was [a result of] the regulation, but also... how can we make ourselves better? To better our work, and be transparent in everything we do, so, the Decree served as a gathering element but all that are part of the [Collective] have benefited from this.

The group of organizations began to talk about a national sector-level body that would coordinate and debate issues within the sector. Many observed that as a first step, the group needed to focus inward.

To explore broader questions about civil society internally, the group of organizations launched several working groups. First, a working group continued to explore the idea of a space for collective representation among organizations in Ecuador. A second working group was created to continue the discussion and drafting of a legal framework for civil society organizations in Ecuador. And third, of most relevance to this article, a working group was set up to explore regulatory mechanisms for civil society outside of government-focusing on transparency and accountability. 


\section{Knowledge Production by Ecuadorian Nonprofit Organizations}

Before 2008, in Ecuador transparency and accountability were not issues on the civil society agenda. But with the implementation of Decree No. 982 and the initiation of the Collective, organizations began to reflect upon and analyze ways to improve organizational transparency and accountability. One of the main challenges was the lack of available information and knowledge about civil society in Ecuador and less so about civil society's transparency and accountability. There was a gap in available information, and this produced a need to collectively generate data and perspectives on the sector, which would then directly influence the curricular content of the training courses developed. The Collective worked on documents that became "position briefs" and helped give meaning to civil society in Ecuador. Collectively, the nonprofit organizations released two public documents: Citizen Contributions to the Regulations of Civil Society Organizations [Aportes Ciudadanos a las Regulaciones de las Organizaciones de la Sociedad Civil del Ecuador] in 2009 and its Manifesto [El Manifiesto] in 2011. These documents permitted the construction of a common vision regarding civil society in Ecuador. In addition, the Collective and organizational participants began a research agenda to develop and collect empirical data on the sector that helped identify capacitybuilding needs, specifically those related to transparency and accountability. Data collection and analysis included an exploratory research project and report by Collective participant CEDA and two collective accountability reports.

Position briefs. In 2009, what was then an informal group quietly released a public document that highlighted main concerns with Decree No. 982. The document was called Citizen Contributions to the Regulations of Civil Society Organizations [Aportes Ciudadanos a las Regulaciones de las Organizaciones de la Sociedad Civil del Ecuador]. In this document, the organizations began to use language about civil society in Ecuador from the perspective of the organizations themselves. The document explains the role of civil society organizations as complementary to the state: "Historically, civil society organizations have provided ideas, goods and social services that have contributed to the improvement ... of communities and the country, especially to the most vulnerable sectors" (Aportes Ciudadanos, 2009, p. 1). The Citizen Contributions document highlights the norms set out in the 2008 Ecuadorian Constitution and in particular, the Constitution's acknowledgment of citizen participation and the construction of a more democratic society. During this time, several Collective participants recognized and explained the work of civil society organizations as fundamental to democracy, as a service to both the government and the public:

This government owes a lot to civil society and NGOs because ideas, programs and political projects were not born [in the government], they were born in the NGOs, many of the ideas that today [that the government] is implementing, that they are talking about, even the discourse, it is not from the government, it is from the NGOs. 


\section{S. Appe \& D. Barragán}

Another important document produced in the early stages of the Collective was a joint statement by organizations, the Collective's Manifesto. On January 7 , 2011, sixty-seven civil society organizations in Ecuador signed a public Manifesto described as a "united message with multiple voices" (Estévez, 2011; OSC Ecuador, 2011). The Manifesto was published in two of the largest newspapers in Ecuador (El Comercio and El Universo) and rejected a new regulation proposed by government in 2010. The Manifesto lays out four agreed-on principles for the Collective of Civil Society Organizations: (a) better understanding of civil society organizations and the nature of civil society; (b) fostering a culture of transparency and accountability mechanisms; (c) respecting the Ecuadorian Constitution; and (d) developing the government's role in protecting and fomenting civil society development (OSC Ecuador, 2011).

\section{Empirical research on the status of transparency and accountability in Ecuador.} In addition to the construction of a civil society discourse and publicly diffused position briefs related to implemented and proposed government regulation, Ecuadorian organizations found it necessary to gather data and make available information about the sector itself. Like the other documents, this collected data and information would directly influence the curricular content of the training courses. In Ecuador, literature about civil society exists (Cabrera \& Vallejo, 1997; Heinrich, 2007; Salazar, 2010; Unda, Guerrero, \& Hidrovo, 2005; World Bank, 2005, 2007), but very little has focused on the sector's transparency and accountability. This situation was motivation to launch investigations in order to generate knowledge about the sector. An exploratory research agenda allowed, first, the creation of a baseline for the situation of transparency across organizations. In Ecuador, there are numerous studies and reports about transparency in relation to the public and for-profit sectors, but this type of study on transparency about the nonprofit sector had not been conducted (Arias, 2011). Second, efforts were made to collectively address issues around accountability, by collecting data on the management practices and programmatic impact of organizations.

In 2010, CEDA conducted an investigation that aimed to understand the perceptions of civil society organizations by different stakeholders. These stakeholders included nonprofit organizations themselves, international aid organizations, government entities, and beneficiaries. The process of collecting and analyzing the data on the perceptions by different stakeholders was crucial to identifying needs related to training for transparency and accountability issues. The investigation, of course, gets at nonprofit organizations' multiple accountabilities as previously mentioned in the literature review. Understanding the perceptions of nonprofit organizations across the accountability domains of upward (e.g., donors) and downward (e.g., constituents, beneficiaries) stakeholders helped define capacitybuilding needs of the sector in Ecuador (Bebbington et al., 2008; Dagnino, 2008; Schmitz et al., 2013). The research methodology was built by CEDA's international partner, the Communication and Development Institute in Uruguay. 
CEDA, however, expanded the methodology by introducing focus groups with beneficiaries of programs and projects of civil society organizations. The focus groups sought to gather the perceptions about nonprofit organizations, what many Ecuadorian organizations recognized as the most important stakeholder for organizations - the beneficiaries. CEDA conducted 31 interviews, organized several focus groups, and led workshops across three cities in Ecuador (Quito, Guayaquil, and Cuenca). In 2011 the research document, "Situation of Transparency and Accountability in Nongovernmental Organizations" [Situación de la Transparencia y Rendición de Cuentas en las Organizaciones No Gubernamentales], ${ }^{3}$ was published and distributed.

Findings from the research show that actors in Ecuador see transparency as a value that should be practiced daily and that organizational culture should be built around. Data derived from organizations themselves show that integrating transparency and accountability is part of an organizational learning process. Some organizations had already developed strategies and tools to ensure accountability. Other organizations have in development such strategies and tools to ensure accountability, pending future implementation. The research report also included tools, mechanisms, and strategies for organizations to replicate, particularly for those organizations that have yet to fully develop accountability mechanisms. For example, tools that were used across many organizations included workshops for the socialization of specific processes and outcomes, such as impact assessment, user satisfaction surveys, communication strategies, and self-regulation mechanisms. Most of the mechanisms related to self-regulation focused on human resources management (e.g., defining roles, identifying capacity-building needs), boards of directors governance (including diversity across members' professional skills, age, and gender), and the creation of internal strategies for strengthening accountability.

Collective accountability reports. With encouragement from its participants and after the well-diffused CEDA report on transparency and accountability, the Collective continued its contribution to knowledge production. It released its first report of aggregated descriptive data on civil society in 2010_ "Report of Collective Accountability 2010" [Informe de Rendicion Colectiva de Cuentas 2010] — and its second, "Report of Accountability 2011" [Informe Rendicion de Cuentas 2011]. Both reports are part of a regional process, the Regional Initiative for Accountability [Iniciativa Regional Rendir Cuentas], that exists now in nine Latin American countries (http://www.rendircuentas.org/).

The first report, "Report of Collective Accountability 2010," is a 25-page document that includes data from 37 organizations and was signed by 11 more organizations in support. It provides descriptive data on participating civil society organizations, making the argument that organized civil society is an "important sector" in Ecuador (Collective of Civil Society Organizations of Ecuador, 2011). The report ties civil society to a strong democracy, arguing that civil society is where many ideas for reform and citizen well-being are initiated, 


\section{S. Appe \& D. Barragán}

mirroring many of the ideas first presented in the public document "Citizen Contributions in 2009" and again in the published January 2011 Manifesto.

The "Report of Collective Accountability 2010" committed the participating organizations to accountability, defined as "an expression of responsibility" and including "transparency and ethics; ... the autonomy of a sector that assumes self-regulation; ... cohesion with which we preach and ask of other actors in society, and ... unity within a diverse sector" (Collective of Civil Society Organizations of Ecuador, 2011, p. 3). The report then provides data on various subjects including where organizations are working, thematic areas of work, who and how many are beneficiaries, information about the amount of money organizations manage, and so on. These data previously had not been aggregated or made available to civil society organizations and the public. Also, the information provided in the document previously had not been covered in media outlets in Ecuador (Collective of Civil Society Organizations of Ecuador, 2011).

The second report of collective accountability, "Report of Accountability 2011," was released publicly on September 2012. The report gathered information from 102 civil society organizations, representing an increase of $175 \%$ from 37 participants in 2010. Based on the lessons learned from the process in 2010, the Collective focused on how to involve more organizations through more personalized outreach and communication; it also provided more technical assistance for filling out the forms during the information gathering (Collective of Civil Society Organizations of Ecuador, 2012).

The report offers a variety of data related to organizational management, coverage, and impact. Specific to transparency, $62.7 \%$ of the organizations audited their financial reports and financial statements; but the Collective determined that there was still room for improvement, because only $52 \%$ of the organizations' audits are accessible to the public. Thirty-five percent of the 102 organizations have a formal policy for receiving funding, but only $25 \%$ make the policy accessible to the public. Although $52 \%$ of the organizations have an ethics code, almost $58 \%$ have no policy directly related to organizational transparency. Based on such data, the report found that transparency and accountability tools needed to be promoted more widely and reinforced the demand for more specialized NME opportunities (Collective of Civil Society Organizations of Ecuador, 2012).

\section{The Development of Training Courses by Nonprofit Organizations}

Through the exchanges among Collective participants and research by the Collective and CEDA, one of the themes most relevant for organizations in Ecuador was the lack of capacity-building and training opportunities for nonprofit leaders in Ecuador. Indeed, CEDA's report finds that a principal weakness of Ecuador's civil society is the lack of knowledge and technical capacity regarding the practice of transparency and accountability (Arias, 2011). The development of training courses on transparency and accountability falls under CEDA's rubric of capacity 
building for nonprofit organizations. Broadly defined, nonprofit capacity building can be considered "increasing the ability of an organization to fulfill its mission" (Wing, 2004, p. 155). However, to better measure capacity building and its effectiveness, its definition needs to be more tailored to the given situation (Wing, 2004). In Ecuador, capacity building is broadly considered a process of strengthening and constructing knowledge and skills related to organizational management. In the context of nonprofit transparency and accountability, this definition becomes about strengthening the knowledge and skills required to use the tools and practices of transparent management and organizational accountability.

As mentioned, few formal NME programs exist in Ecuador. For example, currently an annual open course for nonprofit management exists at the Andean University "Simón Bolívar" [Universidad Andina Simón Bolivar] in Quito, Ecuador; but even if nonprofit managers are aware of the course, they say that it has several weaknesses. The course is targeted for in-service nonprofit managers and is organized into three modules: (a) marketing, (b) project design and administration, and (c) regulatory requirements. The module of marketing is oriented toward improving the ability of the organization to communicate its work; the module of project design and administration allows for the improvement of project formulation and management generally; and the module of legislation addresses the regulations that organizations need to observe. Although these topics are important to organizational management, nonprofit managers observe that specific topics about transparency and accountability are not fully taken into account in the course's academic curricular content. This view is confirmed by a review of the modules' syllabi and conversations with the academic director of the course.

The gap in available training in Ecuador regarding transparency and accountability, in addition to the research results and knowledge production by nonprofit organizations, was further motivation to plan and execute training opportunities on these topics. Led by nonprofit organizations, two courses were offered in Ecuador.

\section{Course 1: Concepts and mechanisms for transparency and accountability.} The course named Moving Forward: Concepts and Mechanisms for Transparency and Accountability of Civil Society Organizations, was organized virtually as a collaborative effort between CEDA and its international partner, Communication and Development Institute from Uruguay, which had experience in this type of online training. The course focused on theoretical frameworks of transparency, experiences in the Latin American region, and good practices related to transparency and accountability. Forty-two participants were selected from more than 80 applicants. Participants were from distinct geographical locations in Ecuador and worked in diverse types of organizations. Most of the participants worked in civil society organizations including foundations, NGOs, and international NGOs. Most participants worked one of three in areas: social development (38\%), democracy and transparency $(21 \%)$, or gender $(12 \%)$. 


\section{S. Appe \& D. Barragán}

The course lasted for three months and was organized into seven modules, which included lecture, a required bibliography, and a recommended bibliography for those who wanted deeper analysis of the themes. The course included exercises that centered on the reflection and evaluation informed by participants' own organizational experiences in order to give them the ability to improve their own organizations' practices.

The course was very well received. A survey to capture the level of satisfaction by participants demonstrated that a significant majority of the participants felt they would bring new knowledge to their organizations. The evaluations were positive; for example, in the words of one participant:

This course has served our organizations, I have already identified some weaknesses that we have and also the strengths. We are going to replicate this course with a group of volunteers that we work with to incentivize civil society. ... In addition, this strengthens us as an organization to establish good accountability and have more credibility in civil society.

The user satisfaction surveys were useful in continuing to build training content as demonstrated in the second pilot course, which is discussed next. However, in Ecuador, nonprofit organizations are still addressing the issue of evaluation and how to measure the effectiveness of capacity building. The nonprofit leaders have not established a rigorous mechanism to evaluate the knowledge acquired based on the comparison of previous knowledge. Current questions on the course evaluations target user satisfaction, as in these examples: "Did the course, in your opinion, meet its objective to advance knowledge and understanding of transparency in Ecuador?" and "Did you find the exchange of information and experiences between the students favorable?” (CEDA, n.d.). Continued examination of evaluative tools that can help to measure the effectiveness of capacity building in transparency and accountability for the nonprofit sector in Ecuador will need to be explored further (Wing, 2004).

Course 2: Tools for transparency and accountability. However, the user satisfaction survey did prove helpful in designing a second pilot course. Participants from the first virtual course indicated on the course evaluations that they felt it necessary to develop more concrete tools that facilitate organizations' ability to improve the transparency of their organizations. Thus a second course was offered, called Training Civil Society Organizations in Tools of Transparency, Accountability and Measuring Impact of Their Management. The course was carried out in collaboration with the Latin American Faculty of Social Sciences [Facultad Latinoamericana de Ciencias Sociales, FLACSO]. The 25 participants were again selected from distinct geographical regions of Ecuador and across different focus 
areas of the organizations, such as environment and water management issues (28\%), transparency (20\%), and social development (16\%).

The course included six modules that followed similar pedagogical principles as in the first course. Although the course this time around was in person, it still included a lecture format, a required bibliography, and a recommended bibliography. The modules were executed through September and November 2011 and elaborated the following themes: (a) transparency policy, (b) legal frameworks that regulate the actions of civil society organizations; (c) tools for monitoring and evaluating organizational impact; (d) management models in social responsibility; (e) strategic communication for transparency and impact; and (f) construction of cross-sector dialogue. Like the first course, the course evaluation showed the participants' positive experiences:

The principal contribution of the course has been the ratification of the importance that the theme has and to take on at personal and institutional levels the challenge of qualifying as a transparency organization. With a lot of satisfaction, I consider that my organization has various tools of transparency and accountability and others that we have to include. They are considered in the proposal to be presented to the Director and staff of the organization.

I have realized two workshops with organizations from the zone..., where lessons were replicated.

In both experiences, the course evaluations (i.e., the user satisfaction surveys) recognized the utility of these types of courses. Although the courses were organized as pilots conducted by nonprofit organizations themselves, they were in response to an intense demand from civil society to strengthen its capacity. Also noteworthy from the evaluations, attendees reported that they intended to replicate the courses at local levels across Ecuador. The intention of local replication shows the interest that exists in Ecuador for information and knowledge related to the transparent and accountable management of nonprofit organizations.

The course evaluations also permitted the identification of opportunities to deepen concrete themes where the need is indicated. For example, CEDA organized a workshop in February 2013 about sustainability reports as integral tools for accountability. A sustainability report is an organizational report that gives information about economic, environmental, social, and governance performance. ${ }^{4}$ The workshop was a joint action with the Collective of Civil Society Organizations and the Ecuadorian Consortium for Social Responsibility [Consorcio Ecuatoriano para la Responsabilidad Social_CERES]. It gave participants strategies to initiate sustainability reports based on guidelines from the International Standards Organization and the Global Reporting Initiative. ${ }^{5}$ According to the facilitators and participants, the shorter workshop format complemented the two longer 


\section{S. Appe \& D. Barragán}

courses and has allowed for more in-depth capacity building of nonprofit leaders in Ecuador.

\section{Lessons Learned and NeXt Steps}

Using Ecuador as a case study, how are nonprofit organizations coping with the lack of formal NME programs and limited curricular content related to transparency and accountability in Latin America? We have identified three strategies: the process of collectivity, the production of knowledge, and the development of training courses. Several lessons are learned from the Ecuadorian case that can inform other countries in Latin America and other contexts beyond the region. When we conducted data analysis for this research, one of the most surprising findings was the emphasis on knowledge production by nonprofit organizations in Ecuador. The two other strategies identified — collectivity and training development - directly benefited from knowledge production. The strategy of knowledge production will inform organizational practice and may encourage dialogue between nonprofit organizations and universities about NME and its curricular content in Ecuador. In addition, the use of transnational networks was critical to the implementation and success of all three strategies and deserves more attention.

In Ecuador, nonprofit organizations have assumed a large role in knowledge production. Nonprofit organizations are collecting data that seek to inform administrative behavior and practice at both the organizational and sector levels. As nonprofit organizations continue to build understanding around the topics of transparency and accountability, capacity in data and knowledge management as well as the creation of information systems in nonprofit organizations will need to become more advanced (see Stoecker, 2007). Scholars also call for a shift in how nonprofit organizations understand data and the need to examine data that might already be collected but not used (Stoecker, 2007). This call might be questioned given some scholars' concerns and cautions about the pervasiveness of managerialism in nonprofit organizations and its implications (see Lewis, 2001; Roberts, Jones, \& Frothling, 2005). Although beyond the scope of this paper, implementing knowledge and data management might create burdens for nonprofit organizations and challenge organizational programming, as some scholars warn. Further research can help assess possible implications and burdens. Additionally, because so much knowledge has been produced recently concerning civil society in Ecuador, research might examine not only how nonprofit organizations and their behavior are influenced but also if such produced knowledge is informing government policy.

Knowledge production by nonprofit organizations should also signal to universities the needs of the sector. Universities are not the only places to gain NME. For example, in Mexico, Benavides (2006) observes that students are often exposed to the subjects of transparency and freedom-of-information issues outside of the formal classroom through seminars, workshops, and conferences. 
Both inside and outside of universities, we have learned that better exchange among universities and nonprofit organizations can advance the creation of better NME programs. Indeed, there have been calls for NME programs to recognize that nonprofit leaders are not just consumers of knowledge but also producers of knowledge (Burlingame, 2009). The work of such special initiatives like the Collective and the knowledge produced, we have found, has not yet highly influenced public affairs education in formal higher education institutions in Ecuador. It is our opinion that the sector will benefit from more dialogue between the nonprofit leaders and universities concerning needs of the sector.

As mentioned, Andean University Simón Bolívar provides a three-module course about nonprofit management (one of the only NME offerings in Ecuador). However, the course does not address many of the current needs of nonprofit organizations in Ecuador. That is, even as transparency and accountability in civil society are debated in the public sphere in Ecuador, both through government regulatory reform and as a result of the production and dissemination of information by the Collective and its partners, these debates have not yet influenced the curricular content of the nonprofit management course at Andean University. Recently, however, in May 2013, the Ecuadorian Consortium for Social Responsibility, with the support of the Andean University Simón Bolívar, has organized a course called Capacity Building on Social Responsibility and Strategic Partnerships for Civil Society Organizations. Carried out through six sessions, the course will cover transparency and accountability under the topic of information management. This step might indicate the start of more inclusion of such issues across the Andina University's coursework related to nonprofit management.

The content of Andean University's nonprofit management course speaks to the debate in the literature on NME programs in regard to the relationship between location and content (see Mirabella \& Young, 2012). In the case of Ecuador, indeed, we have learned that the location of NME programs has largely affected the content of the curricula. Curricular content in the nonprofit management course at Andean University is perceived by nonprofit organizations as very different from the courses offered and led by CEDA. The curricular content framework-market skills, political skills, and management skillsproposed by Young and Grinsfelder (2011) and used by Mirabella and Young (2012) with an addition of philanthropic skills might offer a way to more systematically compare content of NME programs in Ecuador across different locations (e.g., formal universities versus other nonprofit training opportunities). We would encourage such analysis across Latin American countries. Additionally, in the final evaluations of the courses, many nonprofit managers indicated they would replicate many of the courses' themes at the local level across Ecuador. We believe that diffusion and adaptation of NME programs on transparency and 


\section{S. Appe \& D. Barragán}

accountability to the local level deserves greater attention. Such research might help to articulate how universities in particular can better integrate the needs of the nonprofit sector in Latin America and beyond.

In addition to nonprofit organizations constructing more robust NME programs through collectivity, knowledge production, and training development, the roles of transnational networks in these strategies in Latin America deserve more scholarly attention. Although transnational networks have been studiedoften by examining their influence in advocacy at the international level, especially related to human, women's, and environmental rights (Keck \& Sikkink, 1997; Wong, 2012)_little attention has been given to the transnational diffusion of special initiatives (Schmitz et al., 2013) like civil society umbrella organizations (such as the Collective), their objectives, and strategies. Transnational networks are making significant contributions to public affairs education—specifically related to NME and its curricular content - as the Ecuador case shows. Further exchange with Latin American regional networks, such as the Regional Initiative for Accountability [niciativa Regional Rendir Cuentas], and continued work with international partners such as the Communication and Development Institute in Uruguay as well as the Confederation of Colombian Nongovernmental Organizations [La Confederación Colombiana de Organizaciones No Gubernamentales, $C C O N G]$ has the potential to further strengthen NME in Ecuador, Latin America, and elsewhere.

After a process lasting approximately four years, the Collective of Civil Society Organizations was formalized in 2013 into the Ecuadorian Confederation of Civil Society Organizations. The Confederation continues to sign up organizations from across Ecuador, calling on new organizations to join the process; in April 2013, it notarized an act of official incorporation. The Confederation seeks to strengthen and represent its associates, to promote the self-regulation of the sector, and to contribute to the sector's transparency and accountability. Its objectives demonstrate the solidarity built around transparency and accountability through the strategies of collectivity, knowledge production, and training development in Ecuador during the last several years.

\section{ConClusion}

Given the contextual challenges, that is, the limited supply of formal NME programs and its curricular content as well as the implementation of regulatory reform for nonprofit organizations, in addition to the opportunities- the growing interest by organizations to understand, explore, and develop better recognition of ethics, transparent management practices, and accountability mechanisms-Ecuador offers a rich case to explore NME in Latin America. The case of Ecuador reminds public affairs educators that organizations themselves can be successful producers of knowledge and that they can and should create and inform curricular content. It is the responsibility of public affairs educators 
to respond to the needs of nonprofit leaders and the organizations they manage. In contexts like those in Ecuador and beyond, dialogue among public affairs educators in universities and nonprofit leaders regarding curricular content is paramount to an ethical, transparent, and accountable civil society.

\section{NoTES}

1 Nonprofit organizations are considered self-governing entities that do not distribute the excess of their revenues over expenditures among stakeholders, are noncoercive, and are assumed to have a purpose for the public benefit that is agreed upon by associates of the organization (Boris, 2006; Frumkin, 2005; Vakil, 1997). Civil society and nonprofit organizations are also sometimes called third sector organizations, voluntary organizations, or voluntary associations. Depending on the context, terms such as community-based organizations, social organizations, grassroots organizations, and nongovernmental organizations are used, just to name a few. Although in U.S. practice and scholarship the term nonprofit organization is more commonly used, in Ecuador, the term most used is civil society organization. The term nongovernmental organization also appears in Ecuador, as this term is common in the context of international development. Thus, in the case of Ecuador and for this article, we use the terms civil society organization, nonprofit organization, and nongovernmental organization interchangeably.

2 In Ecuador, definitions for civil society and nonprofit organizations, in the Decree, are divided into two groups, foundations and corporations/associations. To be a foundation, an organization must be legalized, be not-for-profit, and engage in activities that promote and develop social, cultural, and educational programs for the public benefit. A corporation must also be legalized and be not-for-profit but is to provide a common good for its members or a determined community. Corporations are further divided into three levels. A first-tier corporation (also called an association) represents a group of people of at least five members, such as clubs, committees, professional groups, and centers. A second-tier corporation is considered an umbrella group of first-tier groups, such as a federation or chamber. And finally, a third-tier corporation is an even more encompassing umbrella group of the second-tier organizations such as confederations, national unions, or similar organizations (Ministry of the Coordination of Social Development, 2008).

3 The digital version can be downloaded at http://www.ceda.org.ec/publicaciones2.php?.pasa=0\&me nu=18\&submenu $1=48 \&$ cod_doc $=2212$

4 For more information, see https:/www.globalreporting.org/information/sustainability-reporting/ Pages/default.aspx

5 For more information, see https://www.globalreporting.org 


\section{S. Appe \& D. Barragán}

\section{REFERENCES}

Abramson, A. J., \& McCarthy, R. (2012). Infrastructure organizations. In L. Salamon (Ed.), The state of nonprofit America (2nd ed.). Washington, DC: Brookings Institution.

Aportes Ciudadanos a las Regulaciones de las Organizaciones de la Sociedad Civil del Ecuador. (2009, August 3). [Citizen contributions to the regulations of civil society organizations in Ecuador]. Quito, Ecuador.

Appe, S. (2011). Civil society mappings by government: A comparison of Ecuadorian and Colombian cases. Journal of Civil Society, 7(2), 157-178.

Arias, A. (2011). Situación de la transparencia y rendición de cuentas en las Organizaciones No Gubernamentales $(O N G)$ del Ecuador [The situation of transparency and accountability in Ecuadorian nongovernmental organizations]. Quito, Ecuador: Centro Ecuatoriano de Derecho Ambiental (CEDA).

Barragán, D. (2010). Rendición de cuentas: De la transparencia a la legitimidad social [Accountability: From transparency to social legitimacy]. Quito, Ecuador: Centro Ecuatoriano de Derecho Ambiental (CEDA). Retrieved from http://lasociedadcivil.org/docs/ciberteca/CEDAanalisis_ No11_marzo_2010.pdf

Barragán, D. (2011). Informe de sistematización del proyecto "Hacia una gobernabilidad transparente: Fortaleciendo la transparencia y rendición de cuentas de las Organizaciones de la Sociedad Civil" (unpublished) [Report of the project "Toward a transparent governance: Strengthening the transparency and accountability of civil society organizations”]. Quito, Ecuador: Centro Ecuatoriano de Derecho Ambiental (CEDA).

Bebbington, A., Hickey, S., \& Mitlin, D. C. (2008). Introduction: Can NGOs make a difference? The challenge of development alternatives. In A. Bebbington, S. Hickey, \& D. C. Mitlin (Eds.), Can NGOs make a difference? The challenge of development alternatives (pp. 3-37). New York: Zed Books.

Benavides, A. D. (2006). Transparency and public administration in Mexico: How the enactment of a law is changing culture. Journal of Public Affairs Education, 12(4), 461-477.

Bies, A. L. (2010). Evolution of nonprofit self-regulation in Europe. Nonprofit and Voluntary Sector Quarterly, 39(6), 1057-1086.

Bies, A., \& Blackwood, A. (2007). Accountability, ethics, evaluation, and governance in nonprofit management education: Trends and treatment. Journal of Public Affairs Education, 13(3/4), 519-547.

Boris, E. T. (2006). Nonprofit organizations in a democracy: Varied roles and responsibilities. In E. T. Boris \& C. E. Steuerle (Eds.), Nonprofits and government: Collaboration and conflict (pp. 399-435). Washington, DC: Urban Institute Press.

Bothwell, R. O. (2001). Trends in self-regulation and transparency of nonprofits in the U.S. International Journal of Not-for-Profit Law, 2(3), 604-622.

Brautigam, D. A., \& Segarra, M. (2007). Difficult partnerships: The World Bank, states, and NGOs. Latin American Politics and Society, 49(4), 149-181.

Brysk, A. (2000). Democratizing civil society in Latin America. Journal of Democracy, 11(3), 151-165. 


\section{Strategies Outside the Formal Classroom}

Burlingame, D. E. (2009). Nonprofit and philanthropic studies education: The need to emphasize leadership and liberal arts. Journal of Public Affairs Education, 15(1), 59-67.

Cabrera, A. C., \& Vallejo, E. P. (1997). El mito al debate: Las ONGs en Ecuador [The myth of the debate: NGOs in Ecuador]. Quito, Ecuador: Alya-Yala Editing.

Centro Ecuatoriano de Derecho Ambiental (CEDA). (n.d.). Evaluación taller de capacitación a capacitadores sobre Ley Orgánica de Transparencia y Acceso a la Información Pública [Workshop evaluation of the training to trainers about the Organic Law of Transparency and Access to Public Information—LOTAIP]. Quito, Ecuador: Author.

Collective of Civil Society Organizations of Ecuador. (2011). Informe de rendición colectiva de cuentas 2010 [Report of collective accountability 2010]. Document on file with the author.

- (2012). Informe rendicion de cuentas 2011 [Report of accountability 2011]. Retrieved from http://rendircuentas.org/wp-content/uploads/2012/10/InformeOSC2011-1_ecuador.pdf

Dagnino, E. (2008). Challenges to participation, citizenship and democracy: perverse confluence and displacement of meanings. In A. Bebbington, S. Hickey, \& D. C. Mitlin (Eds.), Can NGOs make a difference? The challenge of development alternatives (pp. 55-70). New York: Zed Books.

Donmoyer, R., Libby, P., McDonald, M., and Deitrick, L. (2012). Bridging the theory-practice gap in a nonprofit and philanthropic studies master's degree program. Nonprofit Management and Leadership, 23, 93-104. doi:10.1002/nml.21055

Ebrahim, A. (2003a). Accountability in practice: Mechanisms for NGOs. World Development, 31(5), 813-829.

. (2003b). Making sense of accountability: Conceptual perspectives for northern and southern nonprofits. Nonprofit Management and Leadership, 14(2), 191-212.

Estévez, L. (2011). Organizaciones de la Sociedad Ecuatoriana Piden a Gobiernos que no Promulgue Reglamento [Ecuadorian organizations ask governments not to pass the regulation]. Press release.

Frumkin, P. (2005). On being nonprofit: A conceptual and policy primer. Cambridge, MA: Harvard University Press.

Garcés, M. F. (2010, September). Marco normativo para las organizaciones de la sociedad civil [Legal framework for civil society organizations]. Presentation given to the Collective of Civil Society Organizations at Citizen Participation, Quito, Ecuador.

Grupo Legal Trade. (2009, September). Las organizaciones de la sociedad civil en la legislación Ecuatoriana [Civil society organizations in Ecuadorian law]. Quito, Ecuador: Author.

Gugerty, M. K. (2008). The effectiveness of NGO Self-regulation: Theory and evidence from Africa. Public Administration \& Development, 28(2), 105-118.

. (2009). Signaling virtue: Voluntary accountability programs among nonprofit organizations. Policy Sciences, 42(3), 243-273.

Gugerty, M. K., \& Prakash, A. (2010). Introduction. In M. K. Gugerty \& A. Prakash (Eds.), Voluntary regulation of NGOs and nonprofits: An accountability club framework (pp. 3-40). Cambridge: Cambridge University Press. 


\section{S. Appe \& D. Barragán}

Heinrich, V. (Ed.). (2007). CIVICUS global survey of the state of civil society, Volume 1. Bloomfield, CT: Kumarian Press.

Hejka-Ekins, A. (1988). Teaching ethics in public administration. Public Administration Review, 48(5), $885-891$.

International Center for Not-for-Profit Law (ICNL). (2006). Recent laws and legislative proposals to restrict civil society and civil society organizations. International Journal of Not-for-Profit Law, 8(4), 76-78.

. (2009). Barred from the debate: Restrictions on NGO public policy. Global Trends in NGO Law, 1(3), 1-12.

Jackson, T. (2009). A critical cross-cultural perspective for developing nonprofit international management capacity. Nonprofit Management and Leadership, 19, 443-466. doi:10.1002/nml.231

Jordan, L., \& van Tuijl, P. (2006). NGO accountability: Politics, principles and innovations. London: Earthscan.

Kaldor, M. (2003). Civil society and accountability. Journal of Human Development, 4(1), 5-27.

Keck, M., \& Sikkink, K. (1998). Activists beyond borders. Ithaca: Cornell University Press.

Lewis, D. (2001). The management of non-governmental development organizations: An introduction. New York: Routledge.

Martinez, J. M. (1998). Law versus ethics: Reconciling two concepts of public service. Administration and Society, 29, 690.

McAdam, D., McCarthy, J. D., \& Zald, M. N. (Eds.). (1996). Comparative perspectives on social movements. Cambridge: Cambridge University Press.

McCarthy, J. D., \& Zald, M. N. (1977). Resource mobilization and social movements: A partial theory." American Journal of Sociology, 82 (6): 1212-41

Menzel, D. C. (1997). Teaching ethics and values: A survey of graduate public affairs and administration programs in the U.S. PS: Political Science and Politics, 30(3), 518-524.

Ministry of Coordination of Social Development. (2008). Información para las organizaciones de la sociedad civil a ser difundida a través del registro único de organizaciones de la sociedad civil [Information for civil society organization to be diffused through the registry of civil society organizations]. Document on file with the author.

Mirabella, R. M. (2007). University-based educational programs in nonprofit management and philanthropic studies: A 10-year review and projections of future trends. Nonprofit and Voluntary Sector Quarterly, 36(4, Suppl.), 11S-27S.

Mirabella, R. M., Gemelli, G., Malcolm, M.-J., \& Berger, G. (2007). Nonprofit and philanthropic studies: International overview of the field in Africa, Canada, Latin America, Asia, the Pacific, and Europe. Nonprofit and Voluntary Sector Quarterly, 36(4, Suppl.), 110S-135S.

Mirabella, R., \& Young, D. R. (2012). The development of education for social entrepreneurship and nonprofit management: Diverging or converging paths? Nonprofit Management and Leadership, 23, 43-57. doi:10.1002/nml.21049 


\section{Strategies Outside the Formal Classroom}

Najam, A. (1996). NGO Accountability: A conceptual framework. Development Policy Review, 14, $339-354$.

O’Neill, M. (2005). Developmental contexts of nonprofit management education. Nonprofit Management and Leadership, 16, 5-17. doi:10.1002/nml.87

OSC Ecuador. (2011, January 4). Manifesto del Colectivo de Organizaciones de la Sociedad

Civil [Manifest of the Collective of Civil Society Organizations]. Quito, Ecuador: OSC Ecuador.

Prakash, A., \& Gugerty, M. K. (2010). Trust but verify? Voluntary regulation programs in the nonprofit sector. Regulation \& Governance, 4(1), 22-47.

Presidencia de la República del Ecuador [The Office of the President]. (2008, March 25). Executive Decree No. 982. Retrieved from http://decretos.cege.gob.ec/decretos/decretos.aspx?id=2007

Roberts, S., Jones, P., \& Frothling, O. (2005). NGOs and the globalization of managerialism. World Development, 33(11), 1845-1864.

Rutzen, D., \& Shea, C. (2006). The associational counter-revolution. Alliance, 4(3), 27-28.

Salamon, L. M., \& Toepler, S. (2000). The influence of the legal environment on the development of the nonprofit sector. Baltimore: John Hopkins Center for Civil Society Studies.

Salazar, H. (2010). La sociedad civil bajo la lupa [Civil society under scrutiny]. Presentation, Quito, Ecuador. Retrieved from http://www.slideshare.net/videoconferencias/organizacin-de-la-sociedadcivil-y-trabajo-en-redmgs-humberto-salazar

Schmitz, H. P., Raggo. P., \& Bruno-van Vijfeijken, T. (2013). Accountability of transnational NGOs: Aspirations vs. practice. Nonprofit and Voluntary Sector Quarterly, 42, 324-345. doi: $10.1177 / 0899764011431165$

Sidel, M. (2005). The guardians guarding themselves: A comparative perspective on self-regulation. Chicago-Kent Law Review, 80, 803-835.

Stoecker, R. (2007). The research practices and needs of non-profit organizations in an urban center. Journal of Sociology \& Social Welfare, 34(4), 97-119.

Unda, M., Guerrero, J., \& Hidrovo, D. (2005). Luces y sombras. Voces y miradas sobre la sociedad civil en el Ecuador de hoy [Light and shade. Voices and looks about civil society in Ecuador today]. Quito, Ecuador: CIUDAD, Centro de Investigaciones.

Vakil, A. C. (1997) Confronting the classification problem: Toward a taxonomy of NGOs. World Development, 25(11), 2057-2070.

Wing, K. (2004). Assessing the effectiveness of capacity-building initiatives: Seven issues for the field. Nonprofit and Voluntary Sector Quarterly, 33, 153.

Wish, N. B., \& Mirabella, R. M. (1998). Curricular variations in nonprofit management graduate programs. Nonprofit Management and Leadership, 9, 99-110. doi:10.1002/nml.9108

Wong, Wendy (2012). Internal affairs: How the structure of NGOs transforms human rights. Ithaca, NY: Cornell University Press. 


\section{S. Appe \& D. Barragán}

World Bank. (2005). Issues and options for improving engagement between the World Bank and civil society organizations. Washington, DC: Author.

- (2007). Civil society's role in the governance agenda in Ecuador: Assessing opportunities and constraints. Washington, DC: Author.

Worthley, J. A., \& Grumet, B. R. (1983). Ethics and public administration: Teaching what "can't be taught." American Review of Public Administration, 17, 54. doi:10.1177/027507408301700106

Wu, X., \& He, J. (2009). Paradigm shift in public administration: Implications for teaching in professional training programs. Public Administration Review, 69, S21-S28. doi:10.1111/j.15406210.2009.02085.x

Young, D. R., \& Grinsfelder, M. C. (2011). Social entrepreneurship and the financing of third sector organizations. Journal of Public Affairs Education, 17(4), 543-567.

Susan Appe (sappe@binghamton.edu) is an assistant professor of Public Administration at the College of Community and Public Affairs at Binghamton University, SUNY. Her research centers on government-nonprofit relations and the evolution of the nonprofit sector in developed and developing countries.

Daniel Barragán (dbarragan@ceda.org.ec) is a commercial engineer from the Army Polytechnic School in Ecuador. He received an MBA with specialization in project management from the National Polytechnic School and later a specialization in Environmental Management and Sustainability at the Tecnológico de Monterrey. He specializes in development projects management, management of nonprofit organizations, social responsibility, transparency, and civil society issues. In 2008 he joined the World Resources Institute as a Cynthia Helms Fellow. He currently serves as executive director of the Ecuadorian Center for Environmental Law (CEDA). 